\title{
DO AS I SAY, NOT AS I DO. THE APPLICATION OF MUTUAL RECOGNITION AND MUTUAL TRUST
}

\begin{abstract}
Marloes Spreeuw
Summary: This paper focuses on the principles of mutual recognition and mutual trust in the area of justice and home affairs, with which the current Member States are supposed to comply and which are so vigorously applied in the Western Balkans. The growing importance of these principles both for the Member States and the candidate and potential candidate countries will be discussed, since the pre-accession framework is a very powerful tool to export these values and principles to the Western Balkans. In addition, the paper will argue that on the one hand the EU is aware that the current Member States do not comply with these values and principles and the tools available to force the Member States to comply are very weak. On the other hand, the Western Balkan countries are not allowed one step further towards membership if they do not comply with these values and principles. This illustrates that the EU has double standards in the application of its values and principles.
\end{abstract}

\section{Introduction}

Applying the principle of mutual recognition and mutual trust has been the driving force of European integration in the area of justice and home affairs. Strengthening judicial cooperation is and has been in the recent past one of the key priorities for the EU. Applying mutual recognition could lead to more rapid proceedings, would create more legal certainty in the EU, and in general would strengthen judicial cooperation. ${ }^{1}$ The justification for compliance with these principles is based on the values upon which the EU is founded and which are spelled out in the opening parts of the TEU. All Member States are supposed to adhere to these principles and values. Moreover, the pre-accession policy is a very strong tool to export these values and principles to the candidate and potential candidate countries. Consequently, regional cooperation and minimisation and prevention of organised crime, corruption, irregular

\footnotetext{
" PhD researcher, University of Westminster, London, United Kingdom. I would like to thank Dr Adam Łazowski and the participants of the Jean Monnet Seminar 'Advanced Issues of European Law', Dubrovnik, April 2012, for their helpful comments and suggestions.

${ }^{1}$ See Programme of measures to implement the principle of mutual recognition of decisions in criminal matters, OJ C 12/10, 15 January 2001, 1.
} 
migration and trafficking in human beings, ie Justice and Home Affairs (JHA), have become one of the main objectives for the EU in its pre-accession policy concerning the Western Balkans.

With the growing importance of JHA issues in the relations between the EU and the Western Balkans, one would expect first of all compliance with the key principles of mutual recognition and mutual trust of the current Member States. However, a judgment of December 2011 in the joined cases NS $v$ SSHD and ME \& Others $v$ Refugee Applications Commissioner \& $M E J L R,{ }^{2}$ the Assange saga and non-compliance with the European Convention on Human Rights (ECHR) in criminal proceedings all demonstrate that the EU is fully aware that some of its current Member States do not comply with the values and standards which are so vigorously insisted upon with regard to candidate and potential candidate countries. Additionally, the Cooperation and Verification Mechanism established for Romania and Bulgaria in order to monitor the progress that the countries still had to make in the JHA area after joining the EU is not as effective as hoped. They still have to achieve convincing results in the fight against corruption and crime and in reforming judicial practice. This illustrates, firstly, how weak the pre-accession policy can be when candidate countries for membership do not really share the values of the EU but are let in against all the odds. Secondly, it demonstrates the ineffectiveness of post-accession conditionality, eg the Cooperation and Verification Mechanism. Moreover, the existing actions to force Member States to comply with these values and standards are not efficient. The infraction procedure cannot be used to force Member States to comply with the general principles and values of the EU. Therefore, the EU has no tools, apart from article $7 \mathrm{TEU}$, to force the current Member States to comply with these values and principles. However, article 7 has never been activated and it is unlikely that this will happen in the future. Nevertheless, the prospects of candidate and potential candidate countries concerning future membership depend on compliance with these values and principles. This illustrates that the entire system is rather weak and lacks coherent enforcement machinery to guarantee that there are no double standards.

The objective of this paper is to analyse the difficulties that the current Member States encounter in the application of the principles of mutual recognition and mutual trust, and the related issue of the Western Balkans depending on compliance with these principles for their future membership. To cover these issues, this paper is structured so that the second section discusses the growing importance of mutual recognition

\footnotetext{
2 Joined Cases C-411/10 and C-493/10 NS and Others $v$ SSHD and ME \& Others $v$ Refugee Applications Commissioner \& MEJLR nyr.
} 
and mutual trust within the EU and the weakness of the existing tools to enforce Member States to comply with these principles and standards. The third section discusses recent examples showing that the current Member States still struggle in applying the principles of mutual recognition and mutual trust in the area of JHA. The fourth part examines the post-conditionality used for Bulgaria and Romania and comments on its inefficiency. The fifth section focuses on the importance of the principles of mutual recognition and mutual trust in the pre-accession policy for the Western Balkans. Finally, in the last part, the EU's conditionality approach in the pre-accession framework is discussed, illustrating the strength of the future membership incentive.

\section{Judicial cooperation within the EU: substance and enforcement}

The JHA area and more specifically EU criminal law is a rapidly evolving field, where the developments have been remarkable and the growth of EU measures are striking. In order to strengthen judicial cooperation between Member States and to enhance the protection of individual rights, one of the main features of EU law in the field of criminal law at the end of the $20^{\text {th }}$ century and the beginning of the $21^{\text {st }}$ century has been the application of measures related to mutual recognition and mutual trust. ${ }^{3}$ A prerequisite for the implementation of the principle of mutual recognition in criminal matters is that Member States have trust in each others' criminal justice systems. The rationale of the presumption that Member States could have mutual trust in their fellow Member States' criminal justice systems is based on the values upon which the EU is founded and which are spelled out in the opening parts of the TEU. More specifically, as mentioned in the programme of measures to implement the principle of mutual recognition in this field, 'that trust is grounded, in particular, on their shared commitment to the principles of freedom, democracy, and respect for human rights, fundamental freedoms and the rule of law'. ${ }^{4}$

Therefore, it can be argued that European integration concerning JHA matters and in particular criminal law is based on the principles of mutual recognition and mutual trust. However, the actions available to force Member States to comply with these highly important principles in this area are rather weak. First of all, though, since the entry into force of the Lisbon Treaty, the Court has had full jurisdiction to rule on infraction procedures in JHA matters, although with a five-year transnational period for measures adopted before the entry into force of the Lisbon

\footnotetext{
3 Programme of measures (n 1).

4 Programme of measures (n 1) 1.
} 
Treaty. It is extremely difficult to use this action with regard to Member States that do not comply with the common values and principles of the $\mathrm{EU}$, ie the principle of mutual recognition and mutual trust. Secondly, the only serious action available against Member States who do not comply is article 7 TEU. However, article 7 has never been activated and it seems very unlikely that this will happen in the future.

\subsection{The growing importance of mutual recognition and mutual trust within the EU.}

The first developments concerning judicial cooperation within the European Union began with the Council of Europe Conventions in the late $1950 \mathrm{~s},{ }^{5}$ followed by several other Conventions. ${ }^{6}$ The approach to judicial cooperation changed with the entry into force of the Treaty of Amsterdam on 1 May 1999. The Treaty introduced a new objective in article 29 , the development of the Union as an 'area of freedom, security and justice'. Associated with the incorporation of the Schengen acquis into Union law, free movement in an area without internal frontiers was the objective for an area of freedom, security and justice and this became the framework within which EU action on JHA matters would be interpreted. ${ }^{7}$ In order to achieve an area of freedom, security and justice, mutual recognition evolved as the main principle.

In 1998, the UK government, during its EU presidency, proposed to apply the mutual recognition principle in order to enhance judicial cooperation. This led to the recognition at the Cardiff European Council of 'the need to enhance the ability of national legal systems to work closely together ... [and the Council was asked] to identify the scope for greater mutual recognition of decisions of each others' courts. ${ }^{8}$ This approach for improving judicial cooperation in the EU via mutual recognition was upheld in the following years. ${ }^{9}$ In 1999, the European Council in its Tampere Conclusions, setting up a five-year agenda for EU Justice and Home Affairs (JHA), focused on the importance of mutual recognition of judicial decisions. The European Council's view of mutual recogni-

\footnotetext{
5 See for the Convention on extradition 1957, European Treaty Series 24, 86 and 98, and for the Convention on mutual assistance 1959, the European Treaty Series 30 and 99.

6 Convention on the transfer of sentenced persons 1983, European Treaty Series 70 and 112; Convention on Laundering, Search, Seizure and Confiscation of the Proceeds from Crime 1990, European Treaty Series 141. See, for more detail, Steve Peers, EU Justice and Home Affairs Law ( $3^{\text {rd }}$ edn, OUP 2011) ch 9.

7 Valsamis Mitsilegas, EU Criminal Law (1st edn, Hart Publishing 2009) 13.

8 Cardiff European Council, Presidency Conclusions of 15 and 16 June 1998, doc SN 150/11/98 Rev 1, para 39.

9 Valsamis Mitsilegas, 'The Constitutional Implication of Mutual Recognition in Criminal Matters' (2006) 43 CML Rev 1277, 1279.
} 
tion is that it 'should become the cornerstone of judicial co-operation in both civil and criminal matters within the Union. The principle should apply both to judgments and to other decisions of judicial authorities. ${ }^{10}$ The use of mutual recognition with regards to judicial cooperation would improve the traditional system which is slow, cumbersome and uncertain. ${ }^{11}$ According to the Council it could lead to more rapid proceedings, it would create more legal certainty in the EU and in general would strengthen cooperation. ${ }^{12}$ As requested in the Tampere conclusions, the Council adopted a programme of measures to implement the principle of mutual recognition of decisions in criminal matters. ${ }^{13}$ In the following years, this programme was implemented and the first, and most analysed, example of mutual recognition is the Framework Decision on a European Arrest Warrant (EAW), ${ }^{14}$ which replaced the system of extradition between Member States. ${ }^{15}$ Moreover, the Hague Programme of 2004

10 Tampere European Council, Presidency Conclusions of 15 and 16 October 1999, para 33.

11 Commission, Mutual Recognition of Final Decisions in Criminal Matters (Communication) COM (2000) 495 final, 2.

12 Programme of measures (n 1$)$.

13 The programme consisted of 24 very detailed measures which were divided into several chapters. See Programme of measures (n 1); for a discussion of the development of the principle, see Steve Peers, 'Mutual Recognition and Criminal Law in the European Union: Has the Council Got it Wrong?' (2004) 41 CML Rev 5; and Sandra Lavenex, 'Mutual Recognition and the Monopoly of Force: Limits of the Single Market Analogy' (2007) 14 Journal of European Public Policy 762.

14 Council Framework Decision 2002/584/JHA of 13 June 2002 on the European Arrest Warrant and the surrender procedures between Member States [2002] OJ L190.

15 Further mutual recognition measures were adopted with the Framework Decisions on: the execution of orders freezing property and evidence; financial penalties; execution of confiscation orders; a European Evidence Warrant; the transfer of sentenced persons; probation and parole orders; pre-trial supervision orders; recognition of convictions; the exchange of criminal records and in absentia trials. See Council Framework Decision 2003/577/JHA of 22 July 2003 on the execution in the EU of orders freezing property or evidence [2003] OJ L196; Council Framework Decision 2005/214/JHA of 24 February 2005 on the application of the principle of mutual recognition to financial penalties [2005] OJ L76/16; Council Framework Decision 2008/675/JHA of 24 July 2008 on taking account of convictions in the Member States of the European Union in the course of new criminal proceedings [2008] OJ L220/32; Council Framework Decision 2008/978/JHA of 18 December 2008 on the European evidence warrant for the purpose of obtaining objects, documents and data for use in proceedings in criminal matters [2008] OJ L350/72; Council Framework Decision 2008/909/JHA of 27 November 2008 on the application of the principle of mutual recognition to judgments in criminal matters imposing custodial sentences or measures involving deprivation of liberty for the purpose of their enforcement in the European Union [2008] OJ L327/27; Council Framework Decision 2008/947/JHA of 27 November 2008 on the application of the principle of mutual recognition to judgments and probation decisions with a view to the supervision of probation measures and alternative sanctions [2008] OJ L337/ 102; Council Framework Decision 2009/829/JHA of 23 October 2009 on the application, between Member States of the European Union, of the principle of mutual recognition to decisions on supervision measures as an alternative to provisional detention [2009] OJ L294/20; Council Framework Decision 2009/315/JHA of 26 February 2009 on the or- 
and its related Action Plan also encouraged the development of mutual recognition measures. ${ }^{16}$

The development of the Union as an area of freedom, security and justice gained an even more prominent position in the Treaty of Lisbon, which entered into force on December 2009. It now appears in the opening parts of the TEU, where the most important of the Union's objectives are stated. ${ }^{17}$ Moreover, the heading of Title V TFEU, where the provisions on JHA can be found, is also called the 'Area of Freedom, Security and Justice'. Additionally, mutual recognition also obtained an important place in the Lisbon Treaty. The first provision of the Title on the 'Area of Freedom, Security and Justice' states that 'the Union shall endeavour to ensure a high level of security through mutual recognition in criminal matters and, if necessary through the approximation of criminal law'. ${ }^{18}$ The provisions on judicial cooperation in criminal matters also demonstrate the dominant position of mutual recognition in JHA matters. According to article 82(1) TFEU: 'Judicial cooperation in criminal matters in the Union shall be based on the principle of mutual recognition of judgments and judicial decisions'. Furthermore, a legal basis to adopt minimum rules on specific areas regarding criminal matters only exists 'to the extent necessary to facilitate mutual recognition of judgments and judicial decisions. ${ }^{19}$ Mitsilegas argues that this indicates that:

[T] he conferral to the Union of competence to adopt measures in the field of criminal procedure is subordinated to mutual recognition. The adoption of every measure on criminal procedure under this provision must be justified as facilitating mutual recognition. ${ }^{20}$

The above demonstrates that the Treaty of Lisbon provides a proper legal basis for the principle of mutual recognition. ${ }^{21}$ In approximately

ganisation and content of the exchange of information extracted from the criminal record between Member States [2009] OJ L93/23.

16 Peers (n 6) 660.

17 See art 3(2) TEU.

18 Art 67(3) TFEU.

19 Art 82(2) TFEU.

20 Mitsilegas (n 7) 157.

${ }^{21}$ Since the entry into force of the Lisbon Treaty, several measures in the field of criminal law have been proposed and five Directives have been adopted. See Parliament and Council Directive 2010/65/EU of 20 October 2010 on the right to interpretation and translation in criminal proceedings [2010] OJ L280/1; Parliament and Council Directive 2011/36/EU of 5 April 2011 on preventing and combating trafficking in human beings and protecting victims [2011] OJ L101/1; Parliament and Council Directive 2011/92/EU of 13 December 2011 on combating the sexual abuse and sexual exploitation of children and child pornography [2011] OJ L335/1; Parliament and Council Directive 2011/99/EU of 13 December 2011 on the European protection order [2011] OJ L338/2; Parliament and Council Directive 2012/13/EU of 22 May 2012 on the right to information in criminal proceedings [2012] OJ L142/1. 
one and a half decades, mutual recognition and, in parallel with that, mutual trust, have become key principles in the JHA field and have captured a place among the common values and principles upon which the Union is founded.

\subsection{The enforcement of mutual recognition and mutual trust}

With the development of the Union as an area of freedom, security and justice, the principle of mutual recognition that relies on the notion that there is mutual trust between Member States' justice systems based on common standards of respect for the rule of law, democracy and human rights has been at the heart of JHA policy. ${ }^{22}$ Nevertheless, the enforcement machinery available to force Member States to comply with the common values and principles of the EU is not very strong. The Commission, as guardian of the Treaties, can initiate infringement proceedings against Member States that fail to implement Union law and can bring the matter before the Court of Justice. ${ }^{23}$ However, the jurisdiction of the Court of Justice is limited with regards to third pillar measures adopted before the entry into force of the Lisbon Treaty, due to a five-year transnational period. ${ }^{24}$ Even though the Court of Justice has jurisdiction regarding measures adopted after the entry into force of the Treaty of Lisbon, the infringement procedure cannot be used to force Member States to comply with the common values and principles of the EU, such as the rule of law. It can only be activated when a Member State does not comply with or does not implement a specific EU law, and cannot be activated in areas of pure national jurisdiction. The common values and principles upon which mutual trust is based cover extremely broad topics and issues, do not have clear legal definitions, and are inseparable principles. ${ }^{25}$

Therefore, the only serious action that can be activated when Member States do not comply with the common values and principles of the EU is article 7 TEU. The Amsterdam Treaty established the possibility of remedial action by the Union in the event of a serious and persistent breach of common values by a Member State. According to article 7, in a situation where this occurs, the Council 'may decide to suspend certain of the rights deriving from the application of the Treaties to the Member State in question, including the voting rights of the representative of the

\footnotetext{
22 Susie Alegre, Ivanka Ivanova and Dana Denis-Smith, 'Safeguarding the Rule of Law in an Enlarged EU. The Cases of Bulgaria and Romania' CEPS Special Report April 2009, 1 $<$ http://www.ceps.eu> accessed 16 May 2012.

23 Art 258-260 TFEU.

24 Lisbon Treaty Protocol 36 on transnational provisions.

25 Alegre, Ivanova and Denis-Smith (n 22).
} 
government of that Member State in the Council'. Apart from the event of an actual breach, article 7 also provides for a prevention mechanism in the event of a clear risk of a serious breach, which was added by the Nice Treaty. Therefore, article 7 TEU provides the Union institutions with the means of ensuring that all Member States respect the common values and principles listed in article 2 TEU and of which respect for these values and the concern to work together to promote them is a condition for any State which seeks to accede to the Union. ${ }^{26}$ As mentioned by the Commission:

[T]he scope of Article 7 is not confined to areas covered by Union law. This means that the Union could act not only in the event of a breach of common values in this limited field but also in the event of a breach in an area where the Member States act autonomously. ${ }^{27}$

However, article 7 has never been activated and it is not very likely that this will happen in the future. ${ }^{28}$ According to article 2 TEU, the EU is founded upon common standards, such as the rule of law. Nevertheless, the Union has not identified what these standards specifically are, such as a definition of the rule of law in the EU, which is a complex and vague concept surrounded by academic debate. In different legal systems and scholarly literature, there are many diverse views on the substance of the rule of law; it can mean many things and it can mean nothing. ${ }^{29} \mathrm{At}$ the same time, there has been very little discussion regarding the proper conditions in which the action of article 7 can be activated. The reluctance to discuss the possibility of using article 7 at a serious level gives the impression that it is a dead letter in the EU legislative framework. ${ }^{30}$ This demonstrates that the EU does not have very powerful tools to force the Member States to comply with the EU values and principles upon which the Union is based.

\footnotetext{
26 Article 49 TEU. See Commission, Communication to the Council and the European Parliament of 15 October 2003 on Article 7 of the Treaty on European Union. Respect for and promotion of the values on which the Union is based COM (2003) 606 final, 5.

27 Commission (n 26) 5.

28 See for more detail Wojciech Sadurski, 'Adding a Bite to a Bark? A Story of Article 7, the EU Enlargement, and Jörg Haider' Legal Studies Research Paper No 10/01, January 2010, University of Sydney <http://ssrn.com/abstarct=1531393> accessed 4 April 2012.

29 See for more detail, Dimitry Kochenov, 'EU Enlargement and the Failure of Conditionality. Pre-Accession Conditionality in the Fields of Democracy and the Rule of Law' (Kluwer Law International 2008).

30 Alegre, Ivanova and Denis-Smith (n 22) 18.
} 


\section{Difficulties in the application of mutual recognition and mutual trust}

As a result of the EU objective to become an area of freedom, security and justice, cooperation in the area of justice and home affairs and the implementation of mutual recognition and mutual trust became key priorities for the EU. Consequently, the focus of the EU in pre-accession policy was also in the field of JHA, and cooperation in this area constituted a main concern. With the EU's focus on the strict fulfilment of the requirements in this area for the candidate and potential candidate countries of the Western Balkans, one would certainly expect the current Member States to comply with the standards and values of the EU in this field. However, as discussed above, enforcement of the common principles and standards of the EU is rather complicated. A recent judgment of the European Court of Justice demonstrates that the EU is acquainted with the fact that some Member States do not comply with standards and values which are so forcefully applied in the Western Balkans. Moreover, the Assange saga, a highly debated case, and the noncompliance of Member States with the ECHR in criminal proceedings, illustrate the difficulties that Member States still encounter with the principles of mutual recognition and mutual trust.

The joined cases NS $v$ SSHD and ME \& Others $v$ Refugee Applications Commissioner \& MEJLR ${ }^{31}$ demonstrate that Greece does not comply with the EU's policy on asylum, which is 'a constituent part of the EU's objective of progressively establishing an area of freedom, security and justice open to those who, forced by circumstances, legitimately seek protection in the European Union,.$^{32}$ In the course of these proceedings, thirteen Member States, the Swiss Confederation, the United Nations High Commissioner for Refugees, Amnesty International and the AIRE Centre pointed out in their observations that in 2010 Greek external EU land and sea borders accounted for $90 \%$ of all detections of irregular border crossing along all EU external land and sea borders, ${ }^{33}$ 'resulting in a disproportionate burden being borne by that State compared to other Member States and the inability of the Greek authorities to cope with the situation in practice. ${ }^{34}$

\footnotetext{
$31 \quad$ NS (n 2).

32 Court of Justice of the European Union Press Release No 140/11, 'An asylum seeker may not be transferred to a Member State where he risks being subjected to inhuman treatment' (Luxembourg, 21 December 2011).

33 See for more detail, Thematic Situation Report, 'Coping with a Fundamental Rights Emergency: The Situation of Persons Crossing the Greek Land Border in an Irregular Manner' (2011) European Union Agency for Fundamental Rights (FRA).
}

34 Thematic Situation Report (n 33) 2. 
In the first case, NS $v$ SSHD, an Afghan national came to the United Kingdom after travelling through, among other countries, Greece, where he was arrested in 2008 and did not make an asylum application. Four days later he was released and ordered to leave Greece within 30 days. When he arrived in the United Kingdom, he immediately lodged an asylum application, but he was later informed that he would be transferred to Greece, under the Dublin II Regulation, which serves to determine which EU Member State is responsible for examining an asylum application lodged by a third country national on the territory of one of the EU Member States. ${ }^{35}$ Mr N S challenged this decision via legal proceedings where he alleged that there was a risk that his fundamental rights would be infringed were he to be sent back to Greece. In the related case $M E \&$ Others $v$ Refugee Applications Commissioner \& MEJLR, five persons, all unconnected with each other, originating from Afghanistan, Iran and Algeria, travelled via Greece where they were arrested for illegal entry. They then travelled to Ireland, where they claimed asylum. They resisted their return to Greece and claimed that the procedures and conditions for asylum seekers were inadequate in Greece. Under these circumstances, both the Court of Appeal of England and Wales (United Kingdom) and the High Court (Ireland) asked the European Court of Justice whether

in the light of the overloading of the Greek asylum system and its effects on the treatment of asylum seekers and on the examination of their claims - the authorities of a Member State which should transfer the applicants to Greece (the Member State responsible for the examination of the asylum application under the Regulation) must first check whether that State actually observes fundamental rights. ${ }^{36}$

In the judgment of the joined cases, the European Court of Justice upheld the integrity of the common asylum policy but also ensured that asylum seekers' rights are protected. In the judgment, the Court of Justice emphasised the importance of mutual trust for the effective operation of EU asylum law. A key paragraph of the judgment mentions the significance of mutual trust regarding EU cooperation in asylum and in justice and home affairs:

At issue here is the raison d'être of the European Union and the creation of an area of freedom, security and justice and, in particular, the Common European Asylum System, based on mutual confidence

\footnotetext{
35 Council Regulation (EC) No 343/2003 of 18 February 2003 establishing the criteria and mechanisms for determining the Member State responsible for examining an asylum application lodged in one of the Member States by a third-country national [2003] OJ L50.

36 Press Release (n 32) 1.
} 
and a presumption of compliance, by other Member States, with European Union law and, in particular, fundamental rights. ${ }^{37}$

This paragraph places mutual trust at the heart of the area of freedom, security and justice and therefore the Court of Justice held that the slightest infringement of the norm governing the right to asylum cannot be sufficient to prevent the transfer of an asylum seeker to the Member State primarily responsible, since that would deprive the States' obligations in the Common European Asylum System of their substance, and endanger the objective of quickly designating the Member State responsible for examining an asylum claim lodged in the European Union. ${ }^{38}$ The judgment clearly demonstrates that apart from the fact that Greece does not comply with EU asylum law, Member States struggle with the principle of mutual trust. Equally, it is evident from the judgment that compliance with the common principles and standards is very important. Noncompliance weakens the whole system based on mutual trust.

In addition, the Assange saga demonstrates that Member States still encounter difficulties when it comes to the application of mutual recognition and mutual trust, the cornerstones of the objective to develop an area of freedom, security and justice within the EU. Julian Assange, a well-known Austrian national, through his operation in Wikileaks (an international, online, non-profit organisation that publishes submissions of private and classified media from anonymous news sources and news leaks), visited Sweden to give a lecture in 2010. During his time in Sweden he had sexual relations with two women and was later accused of sexual offences. An arrest warrant was issued in November 2010 because Assange was at that time living in England. An extradition hearing took place in an English court in February 2011 to consider the application by the Swedish authority to extradite Julian Assange. At the Belmarsh Magistrates Court, the decision to extradite Assange was upheld, despite the argument that was presented by Assange's lawyers about whether the Swedish prosecutor had the authority to issue a European Arrest Warrant (EAW). On 2 March 2011, Julian Assange appealed to the High Court challenging the decision to extradite him to Sweden. Following the appeal hearing in July 2011 at the High Court in London, the judges dismissed the appeal on 2 November 2011. According to the English High Court:

[I]t cannot be said that the term judicial applies only to a judge who adjudicates. The differing European traditions recognise that others, including prosecutors, can be included within that term for various

$37 \quad$ NS (n 2) para 83 (emphasis added).

$38 \quad$ NS (n 2) para 85. 
purposes. It is therefore entirely consistent with the principles of mutual recognition and mutual confidence to recognise as valid an EAW issued by a prosecuting authority designated under Article 6. To do otherwise would be to construe the word 'judicial' out of context and look at it simply through the eyes of a common law judge, who would not consider a prosecutor as having a judicial position or acting as a judicial authority. ${ }^{39}$

After the dismissal of the High Court, an appeal was lodged at the Supreme Court of the United Kingdom. Initially, the High Court refused permission for an appeal to the Supreme Court; however, the Supreme Court granted permission because a point of law of general public importance was involved. The point of law was whether a prosecutor is a judicial authority that can issue an EAW. On 30 May 2012, the Supreme Court decided by a majority of five to two to dismiss Assange's appeal against extradition. It held that a public prosecutor does fall under the term 'judicial authority' of the Extradition Act 2003. However, since the majority of the Court had based their decision on the interpretation of the Vienna Convention on the Law of Treaties, on which Assange's legal team was not given the opportunity to be heard, they submitted an application to re-open the case on 12 June 2012. Submitting an application to the Supreme Court to re-open a case is extremely rare and there is no precedence that determines the timescale for the Court's decision on the request. Although it is difficult to say to what extent this puts Assange's extradition at risk, the fact that the case has dragged on for over two years demonstrates the problems that Member States still encounter with the principles of mutual recognition and mutual trust.

Moreover, respect for human rights is a requirement for the principle of mutual trust in other Member States' criminal justice systems. One of the most important rights in criminal procedures is the right to a fair trial, which is set out in article $6 \mathrm{ECHR}$ and which is recognised by the Court of Justice as part of the general EU principles. ${ }^{40}$ However, ECHR judgments indicate that some Member States fail to comply with the right to a fair trial. In several judgments, there have been difficulties with the application of the principle of mutual recognition to in absentia trials, where a person moved from one EU Member State to another Member State or who had already resided there before the conviction. The Strasbourg court held that this did not alter the finding that when a defendant is informed of the proceedings and chooses not to attend, but would like to send a legal representative in their place, and the representative is not

39 Case CO/1925/2011 Julian Assange v Swedish Prosecution Authority [2011] EWCH 2849 (Admin), para 41 (emphasis added).

40 See Case C-105/03 Pupino [2005] ECR I-5285. 
allowed to appear, then this is a breach of article $6 \mathrm{ECHR} .{ }^{41}$ As regards freezing orders (provisional measures pending a trial), the court ruled that Bulgaria breached article 6 ECHR which guarantees a trial within a reasonable time, due to the unreasonable time it took to decide on a damages action following an unlawful seizure of goods. ${ }^{42}$ The case law on the right to a fair trial in criminal proceedings is voluminous and this includes breaches by Member States, ${ }^{43}$ such as not informing the defendant of the proceedings, ${ }^{44}$ by using evidence upon which the conviction is based and which is obtained in breach of article 3 of the Convention which entails a breach of article $6,{ }^{45}$ and by confiscating assets on the presumption that the person has committed a crime, while the person has been acquitted of the crime. ${ }^{46}$ The non-compliance of some Member States with the Convention and in particular of article 6 ECHR has adverse effects on the principle of mutual trust in other Member States' criminal justice systems, which forms a key part of the EU's mutual recognition principle.

\section{Post accession conditionality: Romania and Bulgaria}

When Romania and Bulgaria joined the EU on 1 January 2007, they still had progress to make in the fields of judicial reform, corruption and organised crime in order to ensure their capacity to implement and apply measures adopted to establish an area of freedom, security and justice. ${ }^{47}$ For this reason, the Commission decided to establish the Cooperation and Verification Mechanism to monitor progress in these areas after the accession of Romania and Bulgaria. In December 2006, the Commission set specific benchmarks for Bulgaria and Romania in two decisions, one addressed to Bulgaria ${ }^{48}$ and the other addressed to

41 See Cases: Poitrimol v France (1993) Series A no 277-A; Pelladoah v Netherlands (1994) Series A 297-B; Krombach v France App no 29731/96 (ECHR, 13 February 2001).

42 See Patrikova $v$ Bulgaria App no 71835/01 (ECHR, 4 March 2010).

43 See for more detail Peers (n 6) ch 9.3; and Stefan Trechsel and Sarah Summers, Human Rights in Criminal Proceedings (OUP 2005).

44 See Colozza v Italy (1985) Series A no 89; and Sedjovic v Italy App no 56581/00 (ECHR, 1 March 2006).

45 See Jalloh $v$ Germany App no 54810/00 (ECHR, 11 July 2006).

46 See Geerings $v$ Netherlands App no 30810/03 (ECHR 1 March 2007).

47 Commission Decision 2006/929/EC of 13 December 2006 establishing a mechanism for cooperation and verification of progress in Bulgaria to address specific benchmarks in the areas of judicial reform and the fight against corruption and organised crime [2006] OJ L354, 56.

48 Commission Decision 2006/929/EC (n 47). The Commission established six benchmarks that needed to be addressed by Bulgaria: adopt constitutional amendments removing any ambiguity regarding the independence and accountability of the judicial system; ensure a more transparent and efficient judicial process by adopting and implementing a 
Romania. ${ }^{49}$ The creation of the Cooperation and Verification Mechanism has categorised Bulgaria and Romania as the only two countries subject to enduring scrutiny by the Commission after their accession to the European Union..$^{50}$

The Commission reports under the Cooperation and Verification Mechanism every six months on progress in judicial reform, the fight against corruption and, concerning Bulgaria, the fight against organised crime. The first progress reports of June 2007 confirmed that progress achieved in the judicial treatment of high-level corruption cases is still insufficient' in Bulgaria and Romania. ${ }^{51}$ The latest progress report of February 2012, more than 5 years after the accession of both countries, highlighted that further achievement is necessary from Bulgaria in:

adopting the asset forfeiture legislation, taking a more comprehensive approach in reforming judicial and investigative practice, enhancing the role of the Supreme Judicial Council in the reform of the judiciary and achieving convincing results in the fight against corruption and organised crime. ${ }^{52}$

new judicial system act and a new civil procedure code; report on the impact of these new laws and of the penal and administrative procedure codes, notably on the pre-trial phase; continue the reform of the judiciary in order to enhance professionalism, accountability and efficiency; evaluate the impact of this reform and publish the results annually; conduct and report on professional, non-partisan investigations into allegations of high-level corruption; report on internal inspections of public institutions and on the publication of assets of highlevel officials; take further measures to prevent and fight corruption, in particular at the borders and within local government; implement a strategy to fight organised crime, focusing on serious crime, money laundering as well as on the systematic confiscation of assets of criminals; report on new and ongoing investigations, indictments and convictions in these areas.

49 Commission Decision2006/928/EC of 13 December 2006 establishing a mechanism for cooperation and verification of progress in Romania to address specific benchmarks in the areas of judicial reform and the fight against corruption [2006] OJ L354, 56. The Commission created four benchmarks that needed to be addressed by Romania: ensure a more transparent and efficient judicial process notably by enhancing the capacity and accountability of the Superior Council of Magistracy; report and monitor the impact of the new civil and penal procedures codes; establish, as foreseen, an integrity agency with responsibilities for verifying assets, incompatibilities and potential conflicts of interest, and for issuing mandatory decisions on the basis of which dissuasive sanctions can be taken; building on progress already made, continue to conduct professional, non-partisan investigations into allegations of high-level corruption; take further measures to prevent and fight against corruption, in particular within the local government.

50 Eli Gateva, 'Post-Accession Conditionality. Support Instrument for Continuous Pressure?' (2010) KFG Working Paper, Freie Universität <http://www.transformeurope.eu> accessed 16 April 2012.

51 Commission, Report to the European Parliament and the Council of 27 June 2007 on Bulgaria's progress on accompanying measures following accession COM (2007) 377 final; and Commission, Report to the European Parliament and the Council of 27 June 2007 on Romania's progress on accompanying measures following accession, COM (2007) 378 final.

52 See Commission, Interim Report of 8 February 2012 on Progress under the Cooperation and Verification Mechanism in Bulgaria, Memo/12/72. 
For Romania, more progress was expected in:

implementing the new codes, strengthening integrity and accountability within the judiciary, enhancing the dissuasive effect of judicial follow-up to high level corruption cases and ensuring a broad political endorsement of the National Anti-Corruption Strategy. ${ }^{53}$

The ongoing need for the post-accession conditionality, ie the Cooperation and Verification Mechanism, demonstrates that Romania and Bulgaria still do not comply with the standards and values of the EU, which is a condition for the successful development of the Union as an area of freedom, security and justice. Although the Cooperation and Verification Mechanism initially seemed a useful tool for putting political pressure on Romania and Bulgaria to maintain the momentum of improvements that they had demonstrated prior to their EU accession, in practice it is a relatively weak instrument with limited powers to press both Member States into reform. ${ }^{54}$

The slow progress of Romania and Bulgaria in the area of judicial reform and the fight against corruption illustrates that the post-accession incentive is not as effective as the pre-accession ones. After accession, the EU loses its most powerful incentive, which is the prospect of membership, and the rewards concerning accession advancement are no longer available. However, the Treaty of Accession provided for three safeguard clauses, ${ }^{55}$ including a justice and home affairs safeguard clause, which permitted the Commission to establish appropriate measures if there were serious shortcomings or any imminent risk of such shortcomings in the implementation of the acquis in the area of justice and home affairs. The Commission has never invoked the sanctions included in the safeguard provisions. As described by Gateva, there are arguments against the activation of the safeguard clause. Firstly, it would have suspended cooperation in the area of justice and home affairs and in particular the application of the European Arrest Warrant. ${ }^{56}$ Secondly, as argued by Gateva:

The imposition of any of the safeguard provisions would have damaged severely not only the reputation of Bulgaria and/or Romania but also the reputation of the Commission. Furthermore, it would

\footnotetext{
53 See Commission, Interim Report of 8 February 2012 on Progress under the Cooperation and Verification Mechanism in Romania, Memo/12/71.

54 Alegre, Ivanova and Denis-Smith (n 22) 5.

55 The safeguard clauses could be activated until the end of a period of up to three years after accession. See the Act concerning the conditions of accession of the Republic of Bulgaria and Romania and the adjustments to the Treaties on which the European Union is founded [2005] OJ L157.

56 Gateva (n 50) 18.
} 
have discredited the EU's decision to let Bulgaria and Romania become members in 2007 and would have weakened the otherwise declining support for the ongoing enlargement with Turkey and the Western Balkans. ${ }^{57}$

However, despite the arguments against the activation of the safeguard clause, new Member States, including Croatia, will be covered by the safeguard mechanism for three years upon accession, while, for the current Member States, the infraction procedure for pre-Lisbon mutual recognition measures does not apply.

\section{The Westerns Balkans and the principles of mutual recognition and mutual trust}

Although, the current Member States still encounter difficulties in complying with the common principles and values of the EU, these values are vigorously imposed on the Western Balkans. Compliance with the common values and principles of the EU has become one of the cornerstones in the pre-accession policy. Therefore, along with the growing importance of the development of the Union as an Area of Freedom, Security and Justice, regional cooperation in the Western Balkans in the JHA field has become a key priority in the pre-accession policy. The motive for the focus of EU external action in the area of JHA in the Western Balkan countries is based on the view that the internal security of the EU can be improved if EU internal security problems are tackled at their external origin. ${ }^{58}$ Since Bulgaria and Romania joined the EU on 1 January 2007, the Western Balkans, a term used to designate the Southeastern European countries of Croatia, Bosnia and Herzegovina, Serbia, Kosovo, Montenegro, the Former Yugoslav Republic of Macedonia, and Albania, are completely surrounded by EU Member States. Due to war legacies, political instability and a political climate in which organised crime, corruption, irregular migration and trafficking in human beings are common, the Western Balkans developed into an area of concern for the EU. ${ }^{59}$ Minimisation and prevention of these security threats has become a priority for the EU in order to secure an area of freedom, security and justice within the EU.

\footnotetext{
57 Gateva (n 50) 19.

58 Florian Trauner, 'EU Internal Security Policies in the Western Balkans: Analysing the Intersection between Enlargement and Civilian Crisis Management' (2009) paper presented to the $11^{\text {th }}$ Biennial International Conference of the European Union Studies Association <http://www.euce.org> accessed 19 April 2012.

59 Commission, Regional cooperation in the Western Balkans, a policy priority for the European Union (2005) <http://ec.europe.eu> accessed 12 May 2012.
} 
Due to the instability of the region, and uncertain transitions to democracy, the EU has developed a new and more ambitious strategy for the Western Balkans. The countries should be guided in their transformation 'into stable, self-sufficient democracies, at peace with themselves and each other, with market economies and the rule of law, and which will be either members of the EU or in the road to membership'. ${ }^{60}$ To achieve this objective, as mentioned by Trauner, 'the EU decided to apply its most successful foreign policy instrument, ie the incentive of membership. ${ }^{61}$ In May 1999, after a proposal by the Commission, the Stabilisation and Association Process (SAP) was adopted, ${ }^{62}$ which constituted a new framework for EU negotiations with the Western Balkan countries. The SAP aims particularly to support the countries of the Western Balkans to adopt and implement EU law by stabilising the countries and encouraging their swift transition to a market economy, by promoting regional cooperation, all with the prospect of eventual membership of the EU. The SAP is a transformation of the Union's Regional Approach into a more sophisticated policy framework and provides modified and new offers to the Western Balkan countries. ${ }^{63}$ It is based on an evercloser partnership with the EU and offers improved trade concessions, economic and financial assistance, assistance for reconstruction, development and stabilisation, cooperation in justice and home affairs and, most importantly, Stabilisation and Association Agreements (SAAs), a tailor-made category of legally binding agreements between the EU and each country of the Western Balkans. ${ }^{64}$ At the Santa Maria da Feira Council in 2000, the European Council in its Conclusions expressed the possibility of the Western Balkans countries joining the EU:

The European Council confirms that its objective remains the fullest possible integration of the countries of the region into the political and economic mainstream of Europe through the Stabilisation and Association process, political dialogue, liberalisation of trade and cooperation in Justice and Home Affairs. All the countries concerned are potential candidates for EU membership. ${ }^{65}$

\footnotetext{
60 Guoted in Arolda Elbasani, 'The Stabilisation and Association Process in the Balkans: Overloaded Agenda and Weak Incentives?'(2008) EUI Working Paper SPS 2008/03 European University Institute, $1<$ http://cadmus.eui.eu> accessed 25 May 2012.

61 Trauner (n 58) 3.

62 See COM (1999) 235 final, Brussels, 26 May 1999.

63 Steven Blockmans, 'Tough Love. The European Union's Relations with the Western Balkans' (1 ${ }^{\text {st }}$ edn, TMC Asser Press 2007) 251.

64 See Commission's website on Enlargement <http://www.ec.europe.eu/enlargement> accessed 25 May 2012.

65 European Council (2000) Presidency Conclusions, 19 and 20 June 2000 Santa Maria da Feira, point 67.
} 
The Zagreb Summit of Heads of State and Government of the EU Member States and the SAP countries in November 2000 played an essential role in securing the agreement of the regional countries to a clear set of objectives and conditions. ${ }^{66}$ The Final Declaration Stated that 'democracy and regional reconciliation and cooperation on the one hand, and the rapprochement of each of these countries with the European Union on the other, form the whole'. ${ }^{67}$ Furthermore, the heads of regional states or governments committed themselves to establishing:

Regional cooperation conventions providing for a political dialogue, a regional free trade area and close cooperation in the field of justice and home affairs, in particular for the reinforcement of justice and the independence thereof, for combating organized crime, corruption, money laundering, illegal immigration, trafficking in human beings and all other forms of trafficking. These conventions will be incorporated in the stabilisation and association agreements as they are concluded with the European Union. ${ }^{68}$

At the EU Western Balkans Summit in Thessaloniki in June 2003, it was reaffirmed that 'rapprochement with the EU will go hand in hand with the development of regional cooperation' and that the 'SAP will remain the framework for the European course of the Western Balkan countries, all the way to their future accession'. ${ }^{69}$ At the summit, the Council endorsed the so-called 'Thessaloniki Agenda for the Western Balkans: Moving towards European Integration', which strengthened the SAP and supplemented it with elements drawn from the experience of enlargement to Central and Eastern Europe. ${ }^{70}$ Similar to the Accession Partnerships for the Central and Eastern European countries, European Partnerships were launched for the SAP countries to identify priorities for action in supporting the efforts of each specific country to move closer to the EU. Once again, it was confirmed that the need for regional cooperation in the area of justice, freedom and security was a key priority, especially after the Thessaloniki Agenda had emphasised the growing importance of JHA issues in the relations between the EU and the Western Balkan countries. ${ }^{71}$ The concern and the focus of the EU in this area are obvious in the Council Conclusions of the Thessaloniki Agenda which stated that:

\footnotetext{
66 Milica Delevic, 'Regional Cooperation in the Western Balkans' (2007) Institute for Security Studies European Union, Chaillot Paper No 104, July 2007, 41 <http://www.iss. europe.eu> accessed 24 May 2012.

67 Zagreb Summit 24 November 2000, Final Declaration, para 2.

68 European Council (n 65) para 3.

69 For the text of the Thessaloniki Agenda, see Annex A to Council Conclusions of 16 June 2003, Press Release No 10369/03 (Presse 166).

70 Blockmans (n 63) 252.

71 Delevic (n 66) 43.
} 
Organised crime and corruption are real obstacles to democratic stability, sound and accountable institutions, the rule of law, and economic development in the Western Balkans and a source of grave concern to the EU. Combating them must constitute a key priority for the governments of the region. Particular focus should be placed upon fighting all forms of trafficking, particularly of human beings, drugs and arms, as well as smuggling of goods. Although the SAP countries have made some progress, continued efforts at all levels will be crucial to advance further in fighting organised crime. Their commitment must be sustained through effective implementation of all instruments necessary in this combat, including improved administrative and judicial capacity. ${ }^{72}$

\section{Enlargement a powerful incentive: the use of conditionality}

The EU's focus regarding the Western Balkans on regional cooperation and mutual trust in the field of JHA is, as discussed above, linked to the stability of the EU itself. Chris Pattern, as a former EU Commissioner for External Relations, stated: 'The choice for us in this case is very clear: either we export stability to the Balkans, or the Balkans export instability to us'. ${ }^{73}$ With the incentive of future membership, the EU's pre-accession policy is a very powerful tool to export the values and principles upon which the Union is based, including mutual trust and mutual recognition in the JHA area. Regional cooperation and cooperation between the EU and the Western Balkans in the field of JHA is an important requirement of the SAP and a pre-condition to prepare for membership. This was well expressed by the Council of the European Union in the EU's external strategy of December 2005:

The prospect of enlargement is an effective way to align with EU standards in justice and home affairs in candidate countries and those with a European perspective, both through the adoption and implementation of the acquis and through improvements in operational contracts and cooperation. ${ }^{74}$

With the incentive of membership in mind, the academic literature distinguished five mechanisms with which the EU managed to change governance patterns. ${ }^{75}$ The first mechanism is so-called 'gate keeping',

\footnotetext{
72 Thessaloniki Agenda (n 69).

73 Chris Patten, Speech at the Western Balkans Democracy Forum, Thessaloniki, 11 April 2002 <http://ec.europa.eu/enlargement/archives/ear/publications/main/pub-speech_ thessaloniki_20020411.htm> accessed 9 April 2012.

74 Council of the European Union, A Strategy for the External Action of JHA: Global Freedom, Security and Justice, 15446/05, 6 December 2005.

75 See Heather Grabbe, 'Europeanization Goes East: Power and Uncertainty in the EU Accession Process' in Kevin Featherstone and Claudio M Radaelli (eds), The Politics of Eu-
} 
where a country, one step at a time, proceeds towards EU membership. This process begins with the SAP, which is in each case a bilateral affair between the EU and the applicant country. The focal point of the SAP is the conclusion of an SAA which represents a far-reaching contractual relationship between the EU and each Western Balkan country. Proper implementation of the SAA opens the way for the next step on the road to membership, namely, the application for membership. If the EU decides to grant the applicant country real candidate status, which is important because candidate countries can use EU financial assistance in all areas, the next step is the opening of concrete accession negotiations. However, before the accession negotiations can take place, the applicant country has to reach a sufficient degree of general compliance with the Copenhagen Criteria and full cooperation with the International Criminal Tribunal for the former Yugoslavia.

The second mechanism is the models which are the provisions of legislative and institutional templates corresponding with the EU acquis, and harmonisation with EU regulations. However, as expressed by Trauner:

The legal downloading of the acquis was not defined as a top priority for the Western Balkans, given the comparatively low level of European integration and institutional stability. Rather, the SAP was constructed in such a way as to link the agenda of European integration with the stabilisation and transformation of these countries on a more fundamental level. ${ }^{76}$

For the JHA area, this involved four primary areas: police, public order and organised crime; integrated border management; judicial reform; and asylum and migration. In order to achieve European integration in these areas, the EU has a regional strategy to improve regional cooperation in the four key priorities and a country specific strategy, defined in the European Partnerships.

The third mechanism is financial assistance offered within the framework of the Instrument for Pre-Accession Assistance (IPA). ${ }^{77}$ The IPA was established in July 2006, which replaced several instruments for financial assistance, including the Community Assistance for Reconstruction, Development and Stabilisation (CARDS) which was mainly

\footnotetext{
ropeanization (OUP 2003) 312; Florian Trauner, 'Deconstructing the EU's Routes of Influence in Justice and Home Affairs in the Western Balkans' (2009) 31 Journal of European Integration 65.

76 Trauner (n 75) 72.

77 The Legal basis for this assistance is Council Regulation 1085/2006, adopted on 17 July 2006. More detailed implementing rules are laid down in Commission Regulation 718/2007 and in Commission Regulation 80/2010 of 28 January 2010.
} 
dedicated to the region of the Western Balkans. ${ }^{78}$ In the period between 2007 and 2013, total pre-accession funding was EUR 11.5 billion and the proposed amount by the Commission for the period 2014-2020 is EUR 14.1 billion. ${ }^{79}$ Actions funded through IPA are in line with the priorities set out in the European Partnerships for each country and in the enlargement strategy and progress reports published each autumn. In the Commission's proposal for a Regulation on the IPA II of 7 December 2011, justice and home affairs is still a key priority of cooperation within the Western Balkans. The Commission stated:

Making Europe a safer place is high on the EU's agenda as defined in the Stockholm Programme. The improved strategic orientation of financial assistance for pre-accession will help support enlargement countries in preventing and tackling organised crime and corruption and in strengthening their law enforcement, border management and migration control capabilities. ${ }^{80}$

The fourth mechanism is benchmarking and monitoring. Since April 2002, the Commission has used annual Progress Reports to record and monitor achievements and weaknesses and to determine the key priorities for the following year for the Western Balkans. These annual reports are completed with individual country reports, with a specific chapter on cooperation in justice and home affairs. The European Commission's opinion on a country's application for membership is a very important facet of monitoring and forms the basis on which the Council decides to grant an applicant candidate status. Thus far, there has been a Commission opinion concerning Croatia, ${ }^{81}$ the Former Yugoslav Republic of Macedonia, ${ }^{82}$ Montenegro ${ }^{83}$ and Serbia. ${ }^{84}$ When negotiations are approaching, the Commission first examines each chapter with the candidate country, to see how well the candidate country is prepared. This process is known as 'screening'. Subsequently, the Commission reports to the Council on the screening of each chapter, and recommends whether to open negotiations on it or to require that certain conditions, so-called opening bench-

\footnotetext{
78 Council Regulation EC No 2666/2000 of 5 December 2000.

79 Commission, 'Proposal for a Regulation of the European Parliament and of the Council on the Instrument for Pre-accession Assistance (IPA II)' COM (2011) 838 final.

80 Commission (n 79) 4.

81 Commission, 'Opinion on Croatia's application for membership of the European Union COM (2004) 257 final.

82 Commission, 'Opinion on the application from the Former Yugoslav Republic of Macedonia for membership of the European Union' (Communication) COM (2005) 562 final.

83 Commission, 'Opinion on Montenegro's application for membership of the European Union (Communication) COM (2010) 670.

84 Commission, 'Opinion on Serbia's application for membership of the European Union' (Communication) COM (2011) 668 final.
} 
marks, be met first. ${ }^{85}$ However, the Commission can also recommend to open the negotiations and to set closing benchmarks, which should be met in order to close a particular chapter. Benchmarking is a relatively new tool in the enlargement process. The Council agreed upon the use of this instrument in December 2004 after a proposal by the Commission. Its purpose is to improve the quality of negotiations, by providing incentives for the candidate country to undertake necessary reforms at an early stage'. ${ }^{86}$

The last mechanism of Europeanisation is twinning and advice. Launched in May 1998, twinning is a very important tool and assists respective countries in bringing their administrative and democratic institutions in line with European standards in order to help them with the implementation of the EU acquis. As quoted in the Twinning Brochure, 'Building Europe Together', ${ }^{87}$ the contribution of Twinning has been recognised by the European Court Auditors:

Twinning is ... a positive initiative by the European Commission to assist candidate countries in acquiring the capacity to adopt, implement and enforce the acquis communautaire. The Twinning projects acted as a catalyst in setting the candidate countries' reform in motion, bringing together specialists from MS and candidate countries' administrations and promoting the adoption of the Community legislation (...). ${ }^{88}$

The first Western Balkan twinning programme concerning justice and home affairs was the project 'Integrated Border Management: Border Police', implemented in Croatia with Slovenian and German twinning partners between 2002 and 2004.

Apart from the five mechanisms discussed above, the EU's conditionality approach in the Western Balkans has been strengthened through the incentive of visa liberalisation which has encouraged reforms in domestic justice and home affairs in the region. Although the Maastricht Treaty introduced visa policy into the EU framework, the Treaty of Amsterdam developed the EU's visa policy further. ${ }^{89}$ As a result of the Am-

\footnotetext{
85 Commission website (n 64).

86 Commission, 'Enlargement Strategy and Main Challenges 2006-2007. Including annexed special report on the EU's capacity to integrate new members' (Communication) COM (2006) 649 final.

87 Commission, 'Twinning Brochure: Building Europe Together' 2006 <http://ec.europa. eu/enlargement/pdf/twinning_brochure_2005_en.pdf> accessed 14 April 2012.

88 For the full version of the Court of Auditors report, see <http://www.eca.eu.int/audit_reports/special_reports/docs/2003/rs06_03en.pdf> accessed 14 April 2012.

89 The Treaty of Amsterdam introduced Title IV on 'Visas, Asylum, Immigration and other Policies related to Free Movement of Persons' and fell under the first pillar, In addition, the Schengen acquis was integrated into the EU's legal framework.
} 
sterdam Treaty, the EU constructed two lists of third countries, a positive visa list which named the countries whose citizens do not require a visa to enter the EU, and a negative visa list which stated the countries whose citizens do need a visa to enter the EU. ${ }^{90}$ Initially, all Western Balkan countries apart from Croatia were placed on the negative list. This made travelling to the EU for the citizens of the Western Balkans very expensive. In 2003, the Thessaloniki Agenda first introduced the prospect of a liberalised visa regime, depending on the fulfilment of certain conditions:

The EU is aware of the importance the peoples and governments in the Western Balkans attach to the perspective of liberalization of the visa regime. Meanwhile, progress is dependent on these countries implementing major reforms in areas such as the strengthening of the rule of law, combating organised crime, corruption and illegal migration, and strengthening their administrative capacity in border control and security in documents. ${ }^{91}$

In January 2008, readmission agreements entered into force with Serbia, Montenegro, Albania, Bosnia and Herzegovina and Macedonia. This allowed these countries to enter negotiations for free-visa travel. Each of these countries received a roadmap which defined the key areas and the precise conditions to be met in order to move towards visa liberalisation. The roadmaps covered four areas of cooperation: document security; illegal migration and readmission; public order and security; and external relations and fundamental rights. Hence, in addition to membership conditionality, the EU also created a policy conditionality in justice and home affairs in order to motivate the Western Balkans to implement the EU acquis and the values and principles upon which the Union is founded.

Nevertheless, both for membership conditionality and policy conditionality, credibility is vital. As mentioned by Sedelmeier,

credibility has two sides. The candidates have to be certain that they will receive the promised rewards after meeting the EU's demands. Yet they also have to believe that they will only receive the reward if they indeed fully meet the requirements. ${ }^{92}$

\footnotetext{
90 Council Regulation (EC) No 539/2001 of 15 March 2001 listing the third countries whose nationals must be in possession of visas when crossing the external borders and those whose nationals are exempt from that requirement [2001] OJ L81/1.

91 Thessaloniki Agenda (n 69) para 3.

92 Ulrich Sedelmeier, 'Europeanisation in New Member and Candidate States' (2006) 1 Living Reviews in European Governance $12<\mathrm{http}$ ///europeagovernance.livingreviews.org/ Articles/Ireg-2006-3/> accessed 25 May 2012.
} 
If a country receives a reward, in terms of advancing in the stepby-step process, this can be seen as a signal to all the Western Balkan countries. ${ }^{93}$ This is evident in the Commission's Communication concerning the enlargement strategy of 2011-2012, wherein the Commission pointed out that:

The pace at which each country advances towards membership depends mainly on its performance in meeting the established criteria and conditions.

Croatia's successful experience sends strong messages to other enlargement countries:

- The EU delivers on its commitments once the conditions are met.

- The criteria and conditions for accession are demanding and their implementation is monitored with increased attention. This, however, is not an obstacle, but results in the candidate state achieving a higher level of readiness which will benefit both it and the EU upon accession.

- Bilateral disputes with neighbours should and can be addressed through dialogue and compromise, in line with established principles. $^{94}$

However, although Croatia signed the Accession Treaty on 9 December 2011 and will become a Member of the European Union on 1 July $2013,{ }^{95}$ the Commission is still closely monitoring all commitments undertaken by Croatia in the accession negotiations. According to article 36 of the Act of Accession, the monitoring mechanism for Croatia consist of

regularly updated monitoring tables, dialogue under the Stabilisation and Association Agreement between the European Communities and their Member States, of the one part, and the Republic of Croatia, of the other part, peer assessment missions, the pre- accession economic programme, fiscal notifications and, when necessary, early warning letters to the Croatian authorities.

The fight against corruption and the commitments undertaken by Croatia in the area of freedom, security and justice are issues on which

\footnotetext{
93 Trauner (n 75) 72.

94 Commission, 'Enlargement strategy and main challenges 2011-2012 (Communication) COM (2011) 666 final 4.

95 Act concerning the conditions of accession of the Republic of Croatia and the adjustments to the Treaty on European Union, the Treaty on the Functioning of the European Union and the Treaty establishing the European Atomic Energy Community [2012] OJ L112/21.
} 
the Commission has to focus while monitoring Croatia. ${ }^{96}$ The monitoring report of the Commission of April 2012 on Croatia's accession preparations shows the progress that Croatia is still making with regard to both issues. ${ }^{97}$ The report also stipulates specific points that need to be addressed and improved, including a migration strategy ensuring a broader approach to protection of migrants and refuges, and vigilance is required with regard to corruption at the local level, in particular procurement cases. ${ }^{98}$ This demonstrates that even though the accession negotiations with Croatia are closed, the country is still being scrutinised by the Commission, where the JHA area is receiving particular attention.

\section{Conclusion}

Since the entry into force of the Treaty of Amsterdam, the principles of mutual recognition and mutual trust have become crucial elements to realise the objective of the Union as an 'area of freedom, security and justice'. This later obtained an even more prominent position in the Treaty of Lisbon. Together with the growing importance of the development of the Union as an 'area of freedom, security and justice', regional cooperation in the Western Balkans in the JHA area has become a key priority in pre-accession policy. With the incentive of future membership, the pre-accession framework is a very powerful mechanism to export the values and principles of the EU, including mutual trust and mutual recognition in the field of JHA. While all Member States are supposed to adhere to these values and principles, the NS judgment, the Assange saga, and the ECHR case law related to article 6 demonstrate that the EU is aware that some of its Member States do not comply with the values and principles that are so forcefully imposed on candidate and potential candidate countries. Furthermore, the enforcement machinery available to force the current Member States to comply with the principle of mutual trust and mutual recognition is relatively weak, while the preaccession conditionality mechanisms are very strong. This illustrates that there are double standards in the EU regarding the expectations and requirements in the pre-accession policy for the Western Balkans and the compliance and enforcement of the common values and principles with regard to current Member States in the JHA area.

\footnotetext{
96 See Act concerning the conditions of accession (n 95) Article 36.

97 Commission, 'Monitoring report on Croatia's accession preparations' (Communication) COM (2012) 186 final.

98 See for more examples and detail, Commission (n 97) para 2.2.5 and 2.3.
} 
Nonetheless, it is understandable that the EU is very strict towards the Western Balkans regarding fulfilment of requirements in the JHA area, since noncompliance undermines the entire system based on mutual trust, which is a prerequisite for the development of the Union as an area of freedom, security and justice. The Cooperation and Verification Mechanism used for Romania and Bulgaria shows how weak post-conditionality is when Member States do not really share the values of the EU. Hence, compliance with the common values and principles upon which the Union is founded should be one of the cornerstones of pre-accession policy. 